This is an author's accepted version of an article published in the journal: Philosophia. Van Zyl, L. (2009). Accidental rightness. Philosophia, 39, 91-104.

\title{
Accidental Rightness
}

\section{Introduction}

Most modern moral philosophers, including J. S. Mill, Kant and W. D. Ross, argue that an act can be right regardless of the agent's motives. By contrast, some contemporary virtue ethicists like Michael Slote and Rosalind Hursthouse claim that motive is relevant when assessing an act. In this paper I examine a possible argument in favour of including motive in an account of rightness, which I call the problem of accidental rightness: If an act is right because it has good consequences or is in accordance with duty, then it is possible for an act to be right by accident. A closer examination of this argument reveals that the cause of the disagreement between virtue ethicists and modern moral philosophers is that they employ different senses of the term 'right': virtue ethicists tend to use it as interchangeable with 'good' or 'virtuous' and hence as implying praise and admiration, whereas modern moral philosophers use 'right' as roughly equivalent to 'morally obligatory'. Therefore, when they develop a theory of 'right action', the two parties are responding to two very different questions: whereas virtue ethicists focus on what makes an act good, virtuous or worthy of praise and admiration, modern moral philosophers focus on what makes an act obligatory or permissible. I argue that a complete moral theory needs to include an account of both virtuous action as well as moral obligation, and that although modern moral philosophers can rectify their neglect of the notion of acting well or virtuously, it is somewhat harder for virtue ethicists to rectify their neglect of the notion of moral obligation.

\section{The problem of accidental rightness}

Joe, a medical doctor, is dining out in a restaurant when he notices a diner from a nearby table choking on a chicken bone. Joe is not at all inclined to help - indeed, he is somewhat irritated by the disturbance. He continues eating his steak, but then he realises that death in the restaurant will really disturb his meal. Always eager to show off, he senses that coming to the rescue of the 
choking man will impress everyone in the restaurant. He walks over, announces his credentials, and with an impressive nudge dislodges the chicken bone from the man's throat.

Intuitions on whether Joe performed a right act vary. Whereas most people say that Joe's act is right, some find such a claim implausible. The first group can support their intuition by referring to the distinction, made by most modern moral philosophers, between the rightness of an act and the goodness of the agent. For example, J.S. Mill writes that according to utilitarianism, "the motive has nothing to do with the morality of the action, though much to do with the worth of the agent. He who saves a fellow creature from drowning does what is morally right, whether his motive be duty, or the hope of being paid for his trouble" (1979, pp. 17-18). Kant, although emphasising that an act only has moral worth if it is motivated by a sense of duty, still allows that an act motivated by inclination can be right (1984, par. 4:398). In turn, those who find it implausible to say that Joe performed a right act can point out that there are at least a few prominent virtue ethicists, among them Rosalind Hursthouse and Michael Slote, who support their intuition. ${ }^{1}$ For example, Slote considers the case of a prosecutor who convicts a defendant whom he believes to be guilty, but does so from malice, and argues that such an agent acts wrongly, despite performing his duty (2001, pp. 14-15), whereas Hursthouse, in specifying her conception of right action, holds that the agent must act "for the right reason," thus ruling out cases where acts such as helping, facing danger, or telling the truth are done for ulterior reasons or under compulsion (1999, pp. 124-125).

Why do some people find it counterintuitive to say that Joe's act is right? A possible reason is that such a claim commits us to the possibility of an act being right by accident. I will call this the problem of accidental rightness, and it can be formulated as follows:

\footnotetext{
${ }^{1}$ There is at least one version of virtue ethics that does not fully support this intuition, namely Christine Swanton's target-centred account (2001). For the sake of simplicity I will focus on the accounts provided by Slote and Hursthouse, but it is an interesting question how Swanton would respond to the problem of accidental rightness.
} 
If we hold that in saving the life of the choking man Joe performs an act that is morally right (but not well-motivated), then his performing a right act is a matter of sheer luck. To be sure, he does not perform the act by accident, for he has in fact chosen it, but because he didn't choose it for a good reason, it is a matter of luck that the act turns out to be in accordance with duty, and hence right. But the notion of 'accidental rightness' is paradoxical, in the same way that the notion of moral luck is paradoxical: in judging an act to be morally right one is implicitly praising the agent, thus suggesting that he deserves such praise. This shows that character or motive is relevant to rightness: for an agent to deserve praise, he or she must at least have chosen the act, and chosen it for a good reason. So while one could perhaps say that Joe should have helped the choking man, we cannot say that he performed a right act.

Both Slote and Hursthouse appear to have been attracted to a virtue-ethical account of rightness by the intuition that judgements of moral rightness is (or should be) immune to luck. Slote defends an agent-based virtue ethics according to which "treats the moral or ethical status of acts as entirely derivative from independent and fundamental aretaic (as opposed to deontic) ethical characterizations of motives, character traits, or individuals" (2001, p. 5). In defending this approach Slote considers a case where someone with fully benevolent motivation is foiled in her aims and ends up hurting or failing to help the people she (properly) is seeking to help. Slote argues, against consequentialists, that we cannot judge such an act to be wrong:

[I]f someone does make every effort to find out relevant facts and is careful in acting, then I think she cannot be criticized for acting immorally, however badly things turn out.... On the other hand, if the bad results are due to her lack of intelligence or other cognitive defects she is incapable of learning about, we can make epistemic criticisms of her performance, but these needn't be thought of as moral. (If one has cognitive defects one is capable of learning about, but one doesn't care enough to find out about them, then, once again, the genuineness of one's benevolence can be called into question.)... [T]he agent-based assumption that the moral acceptability or rightness of action is insured by having good overall or total motivation is not particularly implausible (2001, pp. 34-35). 
Further down he writes:

...motive is fundamentally at least relevant to the moral character of any action. For if we judge the actions of ourselves or others simply by their effects in the world, we end up unable to distinguish accidentally or ironically useful actions (or slips on banana peels) from actions that we actually morally admire and that are morally good and praiseworthy (2001, p. 39).

Slote's concern here is with avoiding the problem of accidental rightness as it pertains to consequentialist accounts of morality. However, one can expect him to give a similar reply with regard to deontology, namely that if we judge actions by whether they are in accordance with duty, we end up unable to distinguish accidentally 'right' actions - such as Joe's act of helping the choking man - from actions that we actually morally admire and that are morally good and praiseworthy. Slote is led to this view by a sense of fairness, and it is intuitively plausible to those who share his sense of fairness: a benevolent agent does not deserve to be criticised for acting immorally when things turn out badly through no fault of her own. It therefore seems plausible to assume that Slote would argue, in the case of Joe, that his act of helping the choking man should not be described as morally right.

Hursthouse's (neo-Aristotelian) account of right action, in the form that it is presented in the first chapter of On Virtue Ethics, does not provide a clear answer to the question of whether Joe performs a right act. According to this account, "[a]n action is right iff it is what a virtuous agent would characteristically (i.e. acting in character) do in the circumstances” (1999, p. 28). Under one description - as 'helping a choking man' Joe's act is right, but under another - as 'saving a life to show off' - it is not. Hursthouse's more detailed account, in Chapter 6, of what is involved in acting virtuously clearly favours the latter judgement, for her account explicitly rules out cases where someone does what a virtuous person would do for ulterior reasons: "[t]he agent [must act] for a reason and, moreover, for 'the right reason(s)" (1999, pp. 123-124).

So, in short, one might want to conclude from this that one advantage that some versions of virtue ethics have over consequentialism and deontology is that they avoid the problem of accidental rightness. Whereas a consequentialist would judge an act to 
be right if it happens to have good consequences, and a deontologists if it happens to be in accordance with duty, virtue ethicists like Slote and Hursthouse make it a condition for right action that the act be well-motivated.

\section{The right and the good}

At this point deontologists could respond by agreeing that it would be problematical to claim that an agent acts well, or does a good deed, by accident, for an agent who is not well-motivated does not deserve praise. ${ }^{2}$ However, they could point out that they are not claiming that a poorly motivated agent like Joe acts well, or performs a good action. Rather, their claim is that he performs a right act, and by that they mean that he does what he ought to do, or that he fulfils his obligation. The objection from accidental rightness therefore confuses the rightness of an act with its goodness. The phenomenon of 'accidental rightness' does not constitute an example of moral luck, for the very reason that 'rightness' does not imply moral praise and admiration, as the term 'goodness' does. Moral luck is only problematical because it goes against the commonsense intuition that a person's moral standing - whether or not she deserves praise and admiration or the reverse - should be immune to luck, and not be affected by things that are beyond her control. Hence Thomas Nagel writes that we have a case of moral luck "[w]here a significant aspect of what someone does depends on factors beyond his control, yet we continue to treat him in that respect as an object of moral judgement" (1979, p. 26).

An explicit defence of the distinction between the rightness and goodness of acts can be found in W. D. Ross's influential book, The Right and the Good (1930), where he considers the case of a man who pays a particular debt simply from fear of the legal consequences of not doing so. Ross notes that some would say that the man had done what is right, whereas others would deny this, claiming that no moral value attaches to such an act. Ross argues that the latter view is mistaken, and that one reason some people make this mistake is that they confuse the rightness of an act with its goodness. He argues that when we say 'This act is right' we mean 'This is the act that ought to

\footnotetext{
${ }^{2}$ Consequentialists could make much the same response, but for the sake of simplicity I will in the remainder of this paper focus on the way deontologists, mainly Kant and Ross, deal with the distinction.
} 
be done' or 'This act is morally obligatory', whereas when we say an act is morally good we mean that it proceeds from a good or virtuous motive. ${ }^{3}$ He writes:

Moral goodness is quite distinct from and independent of rightness, which ... belongs to acts not in virtue of the motives they proceed from, but in virtue of the nature of what is done. Thus a morally good action need not be the doing of a right act, and the doing of a right act need not be a morally good action. The ethical theories that stress the thing done and those that stress the motive from which it is done both have some justification, for both 'the right act' and 'the morally good action' are notions of the first importance in ethics; but the two types of theory have been at cross-purposes, because they have failed to notice that they are talking about different things (1930, p. 156).

Once we see that by 'a right act' deontologists (and consequentialists) simply mean 'an act that accords with moral obligation', we can understand why they do not consider the phenomenon of accidental rightness problematical. A good illustration of how the paradox disappears when 'right' is taken to mean 'morally obligatory' appears in Michael Stocker's response to view held by Oliver Johnson, namely that an act is not fully right if it is not well-motivated (1959, p. 56). Stocker formulates a possible argument in favour of this view:

One might be tempted here by the Kantian-sounding argument that if one keeps the promise from any except a conscientious motive then it is 'morally speaking, at least' a matter of luck that the obligation is fulfilled. The thought here is that, since the act's being obligatory did not motivate the agent, so far as he was concerned it was a matter of luck that he fulfilled his obligation (1970, p. 601).

\footnotetext{
${ }^{3}$ However, Ross does go on to note a slight difference between the meaning of 'right' and the meaning of 'the act that is morally obligatory'. In some cases the agent ought to do either of two acts, and in such a case either act is right, but neither is obligatory. 'Right' therefore has a somewhat wider application than 'obligatory' (1930, pp. 2-3). In what follows I will use 'right act' as interchangeable with 'an act that accords with our obligations'.
} 
Stocker then goes on to dismiss this argument:

[E]ven if it was a matter of luck ... he did keep his promise, and this is what he promised to do... [T] o fulfil a duty adequately one need not act in as morally good [a] way as possible; one need not do the morally best act possible (1970, p. 601).

I think Stocker's reasoning here is entirely correct, and that Johnson is indeed mistaken in holding that an agent does not adequately discharge his obligation unless he is conscientiously motivated. Once we take 'right' to mean 'in accordance with moral obligation', and distinguish it from good action, the possibility of an act being right by accident simply does not pose a problem. Hence the disagreement about whether Joe's act can be called 'right' turns out to be a verbal disagreement: deontologists use 'right' to mean 'in accordance with moral obligation', whereas those who think he does not perform a right act tie rightness to praiseworthiness and moral worth. It seems, therefore, that Ross's claim remains true, that much of the disagreement in everyday moral practice as well as in normative ethics stems from the fact that the term 'right' is employed in different senses.

I will, for the sake of clarity and simplicity, follow Ross's terminology in the remainder of this paper, using 'good action' to mean one that is praiseworthy, admirable or virtuous, while reserving 'right act' for one that accords with moral obligation. We may then see modern moral philosophers as focusing on developing an account of right action, whereas virtue ethicists such as Hursthouse and Slote are interested mainly in what makes an act good or virtuous. The question we need to consider, then, is whether normative ethicists should focus on developing an account of right action or, instead, an account of what makes an act virtuous. Before considering this question a few comments on Slote and Hursthouse's use of ethical terms are necessary.

Both Slote and Hursthouse make it clear that they are primarily interested in aretaic notions such as good, virtuous, and admirable, rather than deontic concepts such as right, obligatory, or permissible. For example, Slote writes that "an ethics of virtue thinks primarily in terms of what is noble or ignoble, admirable or deplorable, good or bad, rather than in terms of what is obligatory, permissible, or wrong" $(2001$, p. 4). 
Hursthouse similarly explains that virtue ethicists are not happy with the term right action, "with its suggestion of uniqueness, its implication of 'if not right then wrong', and its associations with 'required/obligatory', 'forbidden/prohibited', and 'permissible"" (1999, p. 69). However, whereas virtue ethicists shift the focus from right or obligatory action to virtuous character and action, the significance of this shift is often obscured by the fact that they continue to use deontic terms such as right, permissible, and obligatory. A good example of this is in the following passage, where Slote contrasts acts that are admirable or virtuous with those that are wrong or contrary to obligation:

Acts... do not count as admirable or virtuous for an agent-based theory ... merely because they are or would be done by someone who in fact is admirable or possesses admirable motivation - they have to exhibit, express or further such motivation or be such that they would exhibit, etc., such motivation if they occurred, in order to qualify as admirable or virtuous. By the same token, actions will be wrong or contrary to obligation only if they exhibit bad or deficient motivation (1997, p. 244).

Indeed, as I discuss in more detail elsewhere (20xx), Slote is not entirely consistent in his use of moral terms, and in many instances it is unclear whether he uses right to mean 'in accordance with obligation' or, instead, something more akin to 'virtuous' or 'praiseworthy'. He writes, for example, that according to agent-based virtue ethics, "an act is morally acceptable if and only if it comes from good or virtuous motivation involving benevolence or caring (about the well-being of others) or at least doesn't come from bad or inferior motivation involving malice or indifference to humanity" (2001, p. 38). Most commentators take Slote as providing a criterion of right action in this passage, and indeed, it is clear that by 'morally acceptable' he cannot mean 'virtuous' or 'praiseworthy', given that he allows that an act that is not badly motivated can also be 'morally acceptable'. But it is also possible to understand Slote as saying that such an act is morally acceptable in the sense that it is 'good enough' or 'all right'. What is clear, however, that in discussing what I have called the problem of accidental rightness, Slote is (perhaps unwittingly) uses right action in the sense of good action. In this passage Slote supports the Kantian intuition that we shouldn't fault the actions of someone whose best efforts are undone or misdirected by stepmotherly nature, but most commentators take Kant to be peaking of the goodness (or 
otherwise) of the act in question, rather than about its rightness or wrongness (2001, pp. 34-35). ${ }^{4}$

Hursthouse, in turn, devotes the first chapter of her book to developing an Aristotelian account of right action, which she contrasts to the accounts offered by deontology and consequentialism. She fails to mention in this chapter that the Aristotelian virtue ethicist uses the term 'right action' to mean something very different from what modern moral philosophers mean by it, and indeed, something more akin to what they refer to as 'good action'. It is only in Chapter 3 that she goes on to explain that virtue ethics is primarily concerned with virtuous action, and that it provides an account of right action "under pressure, only in order to maintain a fruitful dialogue with the overwhelming majority of modern moral philosophers for whom 'right action' is the natural phrase" (1999, p. 69). Although I certainly do not want to suggest that Hursthouse is mistaken or confused when she uses 'right' as interchangeable with 'good' or 'virtuous', one unfortunate result of this usage is that it gives the impression that the choice of aretaic over deontic terminology is a relatively trivial matter, and that in giving an account of right action the Aristotelian virtue ethicist is answering the same question that preoccupies modern moral philosophers, namely, 'What makes an act morally obligatory or permissible?'.

Although this matter is all but settled, I will, in the remainder of this paper assume that virtue ethicists such as Slote and Hursthouse shift their focus away from the question of obligation to the question of what makes a person and their actions good (virtuous, praiseworthy, admirable, or acceptable), two sets of questions arise:

1. Are deontologists justified in focusing so much attention on moral obligation? Should they not focus more on developing an account of good or virtuous action?, and, conversely:

\footnotetext{
${ }^{4}$ See Kant (1984, para. 4:394). In the case of the person who helps another out of sympathy rather than a sense of duty he writes: '[I]n such a case an action of this kind, however right and however amiable it may be, still has no genuinely moral worth.' Such an agent acts 'in accordance with duty,' but not 'for the sake of duty,' so that the rightness of an act, conceived as what one has a duty to do, is independent of the motive one might have for performing that act (1984, para. 4:398).
} 
2. Are virtue ethicists justified in focusing their attention on virtue and virtuous action? Shouldn't they also include an account of moral obligation?

In what follows I consider these questions in turn.

\section{Deontology and virtuous action}

There has, over the past few decades, been an a great deal of discussion on the question of whether virtue - and virtuous action - is somehow more important or more fundamental than right action. ${ }^{5}$ In this section I will consider only one possible reason in favour of focusing on virtue, which is a revised version of the problem from accidental rightness, and can be put as follows:

Let us accept that the notion of accidental rightness is not paradoxical, for by 'right' deontologists simply mean 'obligatory' rather than 'praiseworthy' or 'admirable'. But if this is so, it is difficult to see whether in judging an act to be right we are in fact making a judgement that is central to morality, which essentially involves praise and blame, responsibility and choice. In everyday moral practice, what interests us is not only (or even primarily) whether the agent did (or happened to do) what he should have done. In our dealings with others we are interested in what their behaviour reveals about their motives, for this tells us something about their character and hence about what we can expect of them in future. ${ }^{6}$ We also need to know whether we should respond

\footnotetext{
${ }^{5}$ See, for example, Laird (1946), Dent (1975), Larmore (1990), Clowney (1990) and Garcia (1992).

${ }^{6}$ The importance of virtuous action and the question of what a person's actions reveal of his character is brilliantly illustrated in Leo Tolstoy's novel, Anna Karenina. Soon after meeting Anna for the first time, Count Vronsky makes a substantial monetary gift to a woman whose husband - a watchman and the sole provider for a huge family - has just been killed in a train accident. The act is clearly right - perhaps because it has good consequences, or because it is in accordance with duty - but this question is of no significance in the novel. Instead, the central question - upon which, to a large degree, Anna Karenina's fate depends - is whether it is a good deed, revealing
} 
with praise and admiration or the reverse, for such responses encourage certain forms of behaviour while discouraging others. If it is goodness that implies moral praise and admiration, and that has (at least a certain degree of) immunity to luck, then surely, the focus of normative ethics should be on it rather than on rightness and obligation.

This argument can be interpreted in two ways; first, as making the weaker claim that virtuous action is in some sense more important - and hence more deserving of attention - than right action, and, secondly, as making the stronger claim that virtue (and virtuous action) is more fundamental than, or logically prior to, right action. Interestingly, when we consider the weaker version - that virtue is more important than right action - we find that many deontologists will agree. Kant, for example, thinks that nothing is more important to morality than having a good will, which involves having the right motive, and he allows that an act that is right may still have no moral worth $(1984,4: 398)$. Ross echoes this view when he writes, in a much neglected section on the nature of goodness, that:

if we contemplate a right act alone, it is seen to have no intrinsic value. Suppose for instance that it is right for a man to pay a certain debt, and he pays it. This is in itself no addition to the sum of values in the universe. If he does it from a good motive, that adds to the sum of values in the universe; if from a morally indifferent motive, that leaves the sum of values unchanged; if from a bad motive, that detracts from the balance of values in the universe. Whatever the intrinsic value, positive or negative, the action may have, it owes to the nature of its motive and not to the act's being right or wrong; and whatever value it has independently of its motive is instrumental value; i.e. not goodness at all, but the property of producing something that is good (1930, pp. 132$133)$.

It is important to note that, although Ross's theory of good action has received very little attention compared to his account of the right, he himself does not give priority to rightness over goodness. As noted before, Ross states that 'both 'the right act' and

Vronsky to be a truly magnanimous man, or instead, whether it is motivated by a desire to impress others and to enhance his reputation. 
'the morally good action' are notions of the first importance in ethics" (1930, p 156). Part of the reason that Ross's theory of good action has been neglected is that his account of good action makes reference to the right - a good act is one motivated by a sense of duty, the desire to do the right thing. Ross would therefore disagree with the stronger claim - that good action is more fundamental than right action - but he would agree with a slightly weaker version of the weaker claim, namely that 'good action' is at least as important as 'right action', and deserves more attention than it has received.

I will consider the stronger version of the revised objection from accidental rightness (i.e., that virtue - and virtuous action - is fundamental to morality) in the following section. For now we need only note that the weaker version may well be true, that is, that modern moral philosophers have neglected virtue and virtuous action. But if this is all there is to the objection, then there seems to be no reason why deontologists (and consequentialists) cannot rectify this neglect themselves, and indeed, in recent years some have done just that. ${ }^{7}$ The main difference between virtue ethics and deontology comes down to what they have to say about moral obligation, more specifically, about whether it is possible to give an account of good action without making reference to, or relying on a prior notion of, rightness.

\section{Virtue ethics and moral obligation}

There is generally agreement among moral philosophers that, as David Solomon puts it, "any developed ethical theory must include a component that deals with virtue" (1988, pp. 428-429). The more significant - and more controversial - question, to my mind, is whether a complete ethical theory also has to include an account of moral obligation. As suggested earlier, an unfortunate result of virtue ethicists' tendency to use 'right' as more or less interchangeable with 'good' is that it obscures the fact that they have had very little to say about rightness in the sense of moral obligation. It is

\footnotetext{
${ }^{7}$ See, for example Railton (1988), O’Neill (1988 and 1993) and Driver (1988). Some have argued that there is much more agreement between Aristotle and Kant on the issue of moral motivation than is usually supposed, in that both believe that what is involved in acting morally is acting from a reason rather than acting from feeling or inclination. See, for example, Louden (1986) and Korsgaard (1996).
} 
here that the difference between virtue ethics and other moral theories is most striking.

Let us first consider the question of whether virtue ethicists need to provide an account of obligation. Roger Crisp and Michael Slote suggest that they do not, and that the language of obligation can be replaced with aretaic notions (1997, pp. 3-4), and some understand Elizabeth Anscombe's classic paper, "Modern Moral Philosophy" (1958), as making the same claim. ${ }^{8}$ I think there are many cases in which we can say everything we want to say without making use of deontic terms. For example, to capture the intuition that 'something went right' in Joe's case - which deontologists do by saying that he fulfilled his obligation - the virtue ethicist could say that Joe's act of helping the choking man bears some resemblance to, or is the sort of thing a virtuous person would do, but that it cannot be called good or virtuous because his act differs from that of a fully virtuous person in important ways. She could add that this claim does not imply that his act is wrong, or that he should not have helped, for whereas deontic terms tend to be exclusive ('if not right then wrong'), the language of virtue is not. Thus a virtue ethicist might say that Joe should have helped, because it would be callous and cruel to watch a man choke to death when one is able to prevent this. So at least in this and similar cases, there is no need for deontic terminology.

However, I suspect that the reason why we can sometimes do without mentioning obligations in such cases is that they involve what Kantians refer to as an 'imperfect obligations' - that is, obligations to perform a certain act (e.g. to help someone in need, or to give to charity) where there is no corresponding claim on behalf of the other that the act be performed. Imperfect obligations allow for a kind of latitude and are generally believed to be less stringent or binding than 'perfect obligations', which imply a right to compel performance. I think it could well be a good idea to replace the notion of an 'imperfect obligation' with the concepts of virtue, for given their general nature imperfect obligations do not provide clear action guidance in specific cases. (So, for instance, whereas a deontologist can say that Joe has an obligation to

\footnotetext{
${ }^{8}$ However, I agree with Coope that "she was merely inveighing against those who invested notions of 'Ought' and 'Must' and 'Duty' ... with a purely mesmeric force" (2006, p. 22).
} 
help some people some of the time, it is not clear that he has an obligation to help the choking man in this particular case. The virtue ethicist's claim - that a refusal to help would be callous or unkind - is intuitively more plausible.)

However, in cases that involve perfect obligations, that is, where an obligation to some person $\mathrm{Y}$ corresponds to a right or claim by $\mathrm{X}$ that the agent do $\mathrm{Y}$, it is unclear whether virtue ethics has a satisfactory solution. Consider, for example, the case of a parent who provides her child with the necessities of life. Such a parent, according to virtue ethics, acts well, and would act poorly if she failed to provide him with what he needs. This much seems uncontroversial. However, in addition to saying this, it is also appropriate to say that she owes it to the child to do so, or that she has an obligation towards him (provided of course that she is capable of doing so). Here it is some fact about the child, and his relationship to the parent, that makes it her obligation to take care of him, rather than any fact about her character or overall motivation. So, even if it is possible (at least in this kind of case) to give an account of acting well without making reference to obligation, the fact remains that such an obligation does exist so that, if the parent for whatever reason failed to provide the child with what he needs, it is possible for him to claim, not only that he has a nogood mother, but that he has been wronged by her.

Although it may be possible to replace imperfect obligations with talk of what is good or virtuous, it is not clear what virtue ethicists can say about cases that involve perfect obligations, that is, where someone has a specific claim against the agent that she perform a certain act. One possibility is to say that in such cases we have to do with the notion of justice or fairness, which is itself a virtue - a just person is one who gives others what they are due, fulfils her obligations towards others, or respects their rights. Interestingly, in her introduction to On Virtue Ethics, Hursthouse admits that her book has "an obvious gap," and that virtue ethics needs to provide an account of justice. However, she claims that this is a book to be written by political philosophers, not normative ethicists, and then goes on to regret the fact that:

it has become all too common to allow a vague concept of justice and rights to encompass large areas of morality that virtue ethicists believe are better dealt with in terms of other, more concrete, virtues. According to virtue ethicists... what is wrong with lying, when it is wrong, is not that it is unjust (because it 
violates someone's 'right to the truth' or their 'right to be treated with respect') but that it is dishonest, and dishonesty is a vice.... From the perspective of virtue ethics, one can say that it is 'absolutely required' that one does not 'pass by on the other side' when one sees a wounded stranger by the roadside, but the requirement comes from charity rather than justice (1999, p. $6)$.

I think the latter claim is possibly correct, that cases involving wounded (or choking) strangers are better dealt with in terms of the virtues than rights. However, there are many instances where we do need the language of rights and obligations. While it is generally true that one should not lie because lying is dishonest (and dishonesty a vice), there will be some cases where one cannot fully explain why one should not lie without making reference to rights and obligations. For example, when a woman discovers that her sexual partner has been lying to her about his HIV-status, she can complain that her partner (or, more likely, ex-partner) is malicious and selfish, but this still does not capture the intuition that she is a victim of his lie, that she has been wronged. I think many (perhaps most) of our everyday moral decisions do involve issues of justice: questions, for example, about what parents owe their children, what patients can legitimately expect from health care professionals, husbands from wives, and vice versa.

Furthermore, I would argue that an account of what is right, just or morally obligatory is presupposed by the practice of assigning moral praise and blame. To see this, let us consider Slote's case, discussed at the beginning of this paper, of an agent (let us call her Mary) who has a fully benevolent motivation but is foiled in her aims and ends up hurting or failing to help the people she (properly) is seeking to help (2001, pp. 3435). As we have seen, Slote argues that if Mary makes every effort to find out relevant facts and is careful in acting, she cannot be criticised for acting immorally. But now note that in arguing thus, Slote is making an appeal to our sense of fairness, to the intuition that she does not deserve blame, that she ought not to be criticised. But just where does this 'ought' come from? Of course, it could be argued that a sense of fairness (or justice) is itself a virtuous motive, so that by applying a virtue-based theory we could say that if John unfairly blames Mary for hurting people, he fails to act well. However, for us to criticise John for failing to act well, without ourselves being guilty of blaming him unfairly, we need to be sure that he was not motivated by 
a sense of fairness in blaming her. After all, it could be the case that John is motivated by a sense of fairness - that he took care to find out the facts, and genuinely believes that Mary deserves blame - but that he is misinformed in so thinking. In such a case we would have to conclude that John's act of blaming Mary is motivated by the virtue of justice, and hence is a good act. However, this judgement does not capture the claim that Slote also wants to make, namely that Mary does not deserve blame, and that if John blamed her she is being treated unfairly.

In much the same way, Hursthouse appeals to a theoretically prior notion of justice in her discussion of the case of two parents who each give their daughter a present. She notes that saying that they do what is permissible fails to capture the fact that they act well, thereby "fail[ing] to do justice to" the two agents. She writes: "What they do merits more in the way of assessment, for they do not do what is merely permissible, but act generously and hence well" (1999, p. 69). What this shows is that justice or fairness is an independent moral standard (or set of standards), and one that is presupposed by the very practice of praising and blaming agents for their conduct by calling their actions good or virtuous or admirable. An act is unjust, not because of what motivates it, but because it does not give someone what they are due, or violates an obligation to someone. A moral theory that focuses only on the goodness (or otherwise) of actions is unable to account for the fact that others have claims against us, or conversely, that we owe it to them to treat them in certain ways. And such a theory is incomplete. There are a number of ways in which this gap can be filled, for instance by appealing to Rossian prima facie duties, the principle of utility, or some social-contract theory. Perhaps the most plausible strategy, in my view, is to see justice as a set of rules or conventions stating which rights and obligations people have, and which is adopted by a community to make it possible for members of that society to flourish or live the best life possible. ${ }^{9}$ Of course, none of these strategies are available to foundationalists like Slote, for his account treats virtue as fundamental. But it may be available to coherentist accounts like that of Hursthouse, which treat virtue as central without claiming that it is fundamental.

\section{Conclusion}

${ }^{9}$ Miller (2006) goes some way towards developing such a theory. 
I began this paper by considering the problem of accidental rightness as a possible objection to deontology, namely that if we hold that a right act is one that is in accordance with duty, then it is possible to perform a right act by accident, or as a matter of luck. According to this objection, the term 'right' implies praise, making it contradictory to judge a badly motivated act to be right. In response, deontologists can point out that they agree that the act is not good or praiseworthy, and that when they say the act is right they simply mean that it is the act that ought to be performed, one that is obligatory. At this point the objector could argue that, if this is the case, that is, if in describing an act as right (or obligatory) deontologists do not imply that the act has moral value or that the agent deserves praise, then it is difficult to see why they have lavished so much attention on rightness. I argued that although deontologists can rectify their neglect of good action - and do so without thereby taking virtue as more fundamental, the more difficult question for virtue ethicists is whether they are able to provide a satisfactory account of moral obligation or, failing that, whether they can show that we can get rid of the notion of obligation altogether. I argue that virtue ethicists do need to give an account of moral obligation, and that such an account is presupposed by the practice of assigning moral praise and blame.

\section{References}

Anscombe, E. (1958). Modern moral philosophy, Philosophy 33.

Clowney, D. (1990). Virtues, rules, and the foundations of ethics. Philosophia 20: 4967.

Coope, C. M. (2006). Modern virtue ethics. In T. Chappel (Ed.), Values and Virtues: Aristotelianism in Contemporary Ethics. Oxford: Clarendon Press.

Crisp, R. and Slote, M. (1997). Virtue Ethics. Oxford: Oxford University Press.

Dent, N. J. H. (1975). Virtues and actions. The Philosophical Quarterly 25: 318-335.

Driver, J. 1988. The virtues and human nature. In R. Crisp (Ed.), How Should One Live? Essays on the Virtues. Oxford: Clarendon Press.

Garcia, J. L. A. (1992). The right and the good. Philosophia 21: 235-256.

Hursthouse, R. (1999). On Virtue Ethics. Oxford: Oxford University Press.

Johnson, O. A. (1959). Rightness and Goodness The Hague: Marthinus Nijhoff Press.

Kant, I. (1984). Groundwork of the Metaphysics of Morals. H. J. Paton (Trans.) New York: Harper \& Row. 
Korsgaard, C. (1996). From duty and for the sake of the noble: Kant and Aristotle on the morally good action. In S. Engstrom and J. Whiting (Eds.), Aristotle, Kant and the Stoics (pp. 203-236), Cambridge: Cambridge University Press.

Laird, L. (1964). Act-ethics and agent-ethics. Mind 55: 113-132

Larmore, C. (1990). The right and the good. Philosophia 20: 15-32

Louden, R. B. (1986) Kant's virtue ethics. Philosophy 61: 473-489.

Miller, F. (2006). Virtue and rights in Aristotle's best regime. In T. Chappel (Ed.),

Values and Virtues: Aristotelianism in Contemporary Ethics. Oxford: Clarendon Press.

Nagel, T. (1979). Moral Luck. In Mortal Questions. Cambridge: Cambridge University Press.

Mill, J. S. (1979). Utilitarianism. G. Sher (Ed.) Indianapolis: Hackett.

O’Neill, O. (1988). Kant's virtues. In R. Crisp (Ed.), How Should One Live? Essays on the Virtues. Oxford: Clarendon Press.

O’Neill, O. (1993). Duties and virtues. Philosophy 35 (Supplement)

Railton, P. (1988). How thinking about character and utilitarianism might lead us to rethinking the character of utilitarianism. In P. A. French, T. E. Uehling Jr., and H.

Wettstein (Eds.), Midwest Studies in Philosophy Volume XIII Ethical Theory:

Character and Virtue. Notre Dame, IN: University of Notre Dame Press.

Slote, M. (1997). Agent-based virtue ethics. In R. Crisp and M. Slote (Eds.), Virtue Ethics. Oxford: Oxford University Press.

Slote, M. 2001. Morals from Motives. Oxford: Oxford University Press.

Solomon, D. (1988). Internal objections to virtue ethics, in French et al.

Ross, W. D. (1930). The Right and the Good. Oxford: Clarendon Press.

Stocker, M. (1970). Intentions and act evaluations. The Journal of Philosophy 67 (17).

Swanton, C. (2001). A virtue-ethical account of right action. Ethics 112: 32-52. 